International Journal of Current Microbiology and Applied Sciences ISSN: 2319-7706 Volume 9 Number 2 (2020)

\title{
Eco-friendly Management of Anthracnose Disease of Cowpea (Vigna unguiculata) Sacc. \& Magn
}

\author{
Maria Modi* and Shashi Tiwari \\ Department of Plant Pathology, Sam Higginbottom University of Agriculture, Technology and \\ Sciences, Allahabad- 211007 (U.P.), India \\ *Corresponding author
}

Keywords

Anthracnose,

Colletotrichum

lindemuthianum,

bio-agents,

botanicals.

Article Info

\section{Accepted:}

20 January 2020

Available Online:

10 February 2020

\section{A B S T R A C T}

An experiment was conducted at experimental field of Plant Pathology, Sam Higginbottom University of Agricultural, Technology and Sciences, Allahabad, during the kharif season 2017 to evaluate the effect of botanicals and bio-agents against Anthracnose of Cowpea caused by Colletotrichum lindemuthianum. Eight treatments including control replicated thrice in Randomized block design. In field experiments, the highest reduction of disease intensity was achieved by Trichoderma viride (23.703) and Pseudomonas fluorescens (25.550) @ 2\% at 30, 60, 90 DAS. Under invitro condition Eucalyptus oil @ 5\% was found most effective inhibiting mycelial growth (100\%) followed by Trichoderma viride $(68.82 \%)$. All the treatments significantly reduced the Anthracnose disease under field conditions.

\section{Introduction}

The first written reference of the word 'cowpea' appeared in 1798 in the United States (Small, Ernest 2009). The name was most likely acquired due to their use as a fodder crop for cows (Timko et al., 2007). The cowpea (Vigna unguiculata) is an annual herbaceous legume from the genus Vigna. Cultivated cowpeas are known by the common names black-eyed pea, southern pea, yardlong bean, catjang, and crowder pea. It belongs to the family Fabaceae and probably a native of Central Africa.

Cowpea is also a kharif legume crop and is grown across India for seeds, green pods, animal fodder, and organic green manure. It is called as vegetable meat due to high nutritious constitutions with high protein $23-24 \%$, carbohydrate $60.3 \%$, minerals and vitamins and also rich source of iron and calcium. The size and shape of the leaves varies greatly, making this an important feature for 
classifying and distinguishing cowpea varieties. Flower colour varies through different shades of purple, pink, yellow and white and blue (National Research Council 2006).

The term 'Anthracnose' literally means 'like coal' and was first used by Fabre and Dunal to describe a disease of grapes in which blackening of tissue was a characteristic feature. In Nigeria, the disease is one of the major fungal diseases of cowpea crop. The fungus overwinters in the previous crop debris, and can also be seed-borne as dormant mycelia within the seed coat or as spores between the cotyledons; from where it initiates infection of hypocotyls and young leaves in the field.

The management of plant diseases generally include strategies such as physical and cultural control, resistant cultivars, chemical and biological control. The integration of different management practices has the potential to provide an effective strategy for the control of Anthracnose of Cowpea. Some bio-control agents have been reported as a promising disease management tool.

\section{Materials and Methods}

The experiments were carried out during kharif season of 2017-2018 at Department of Plant Pathology, Sam Higginbottom University of Agriculture, Technology and Sciences, Allahabad. The experiment was conducted in randomized block design with seven treatments and one control (untreated). The fields were made weed free, ploughed and pulverised. Further, the plots were divided into 24 sub plots. The bunds and irrigation channels were made. The seed were sown @ of 20-25 kg/ha by the method of line sowing with the spacing of $30 \mathrm{~cm}$ between row to row and $15 \mathrm{~cm}$ between plant to plant. Observations recorded were disease severity and plant height at 30,60 and 90 DAS. After harvesting yield were also recorded.

\section{Results and Discussion}

Study entitled, "Eco-friendly management of Anthracnose disease of Cowpea (Vigna unguiculata) Sacc. \& Magn" was conducted at the Central Research Farm, Department of Plant pathology, Sam Higginbottom University of Agriculture, Technology and Sciences, Allahabad, Uttar Pradesh during the Rabi season of 2017-18 in randomized block design having seven treatments and one control $\left(\mathrm{T}_{0}\right)$.

The data of 30 DAS shows that the control (39.92) has the highest disease intensity. Minimum disease intensity was recorded in Trichoderma viride @ 2\% (12.72), followed by Pseudomonas fluorecsens @ 2\% (15.81), Eucalyptus oil @5\% (18.33), Neem oil@ 5\% (22.336), garlic bulb extract @ 5\% (24.103),Tulsi leaf extract @ 5\% (25.866) and Datura leaf extract @ 5\% (29.263). Trichoderma viride shows the best result when it was checked 30 DAS. The statistical analysis of data showed that all treatments were found significantly effective and significant over control.

These results were observed invitro conditions. As we can clearly see from Table 2 , that only one botanical exhibits the inhibition of Colletotrichum lindemuthianum completely which is Eucalyptus oil with Radial Growth of $0.00 \mathrm{~mm}$,with 100 percent inhibition followed by Trichoderma viride with 68.82 inhibition per cent, Neem oil with 62 inhibition per cent, Datura 61.17 inhibition percent, Tulsi leaf extract with 59.81 per cent, Garlic bulb extract with 56.87 per cent and Pseudomonas fluorecsens with least inhibition percent i.e. $53.34 \%$. The statistical analysis of data showed that all treatments were found significantly effective and significant over control. 
Table.1 Cowpea at different days of interval

\begin{tabular}{|c|c|c|c|c|}
\hline \multirow{2}{*}{ Tr. No. } & TREATMENT & \multicolumn{3}{|c|}{ DISEASE INTENSITY } \\
\cline { 5 - 5 } & NAME & $\mathbf{3 0}$ & $\mathbf{6 0 D A S}$ & $\mathbf{9 0 D A S}$ \\
\hline $\mathbf{T}_{\mathbf{0}}$ & Control & 39.926 & 54.730 & 67.070 \\
\hline $\mathbf{T}_{\mathbf{1}}$ & Datura leaf extract & 29.263 & 36.313 & 45.810 \\
\hline $\mathbf{T}_{\mathbf{2}}$ & Tulsi leaf extract & 25.866 & 32.666 & 43.086 \\
\hline $\mathbf{T}_{\mathbf{3}}$ & Garlic bulb extract & 24.103 & 28.326 & 38.576 \\
\hline $\mathbf{T}_{\mathbf{4}}$ & Neem oil & 22.336 & 27.613 & 32.753 \\
\hline $\mathbf{T}_{\mathbf{5}}$ & Eucalyptus oil & 18.333 & 26.936 & 30.020 \\
\hline $\mathbf{T}_{\mathbf{6}}$ & Trichoderma viride & 12.720 & 20.706 & 23.703 \\
\hline $\mathbf{T}_{\mathbf{7}}$ & Pseudomonas & 15.810 & 25.333 & 25.550 \\
\hline & fluorescens & & & \\
\hline & $\mathbf{F}$ Test & $\mathbf{S}$ & $\mathbf{S}$ & $\mathrm{S}$ \\
\hline & S. Ed. $\mathbf{( \pm )}$ & 0.34 & 1.42 & 2.31 \\
\hline & $\mathbf{C D}(\mathbf{0 . 0 5 \% )}$ & 1.49 & 3.04 & 3.88 \\
\hline
\end{tabular}

Table.2 Invitro evaluations of botanicals and bio-agents against Colletotrichum lindemuthianum

\begin{tabular}{|c|c|c|}
\hline Treatment & Radial growth $(\mathbf{m m})$ & $\begin{array}{c}\text { \% Growth } \\
\text { inhibition }\end{array}$ \\
\hline $\mathbf{T}_{\mathbf{0}}$ Control & 85 & 0.00 \\
\hline $\mathbf{T}_{\mathbf{1}}$ Datura leaf extract & 33 & 61.17 \\
\hline $\mathbf{T}_{\mathbf{2}}$ Tulsi leaf extract & 34.16 & 59.81 \\
\hline $\mathbf{T}_{\mathbf{3}}$ Garlic bulb extract & 36.66 & 56.87 \\
\hline $\mathbf{T}_{\mathbf{4}}$ Neem oil & 32.33 & 62 \\
\hline $\mathbf{T}_{\mathbf{5}}$ Eucalyptus oil & 0.00 & 100 \\
\hline $\mathbf{T}_{\mathbf{6}}$ Trichoderma viride & 26.50 & 68.82 \\
\hline $\mathbf{T}_{\mathbf{7}}$ Pseudomonas & 39.66 & 53.34 \\
\hline fluorescens & $\mathrm{S}$ & - \\
\hline F Test & 0.12 & - \\
\hline Sem & 0.88 & - \\
\hline CD $(\mathbf{0 . 0 5 \% )}$ & & \\
\hline
\end{tabular}




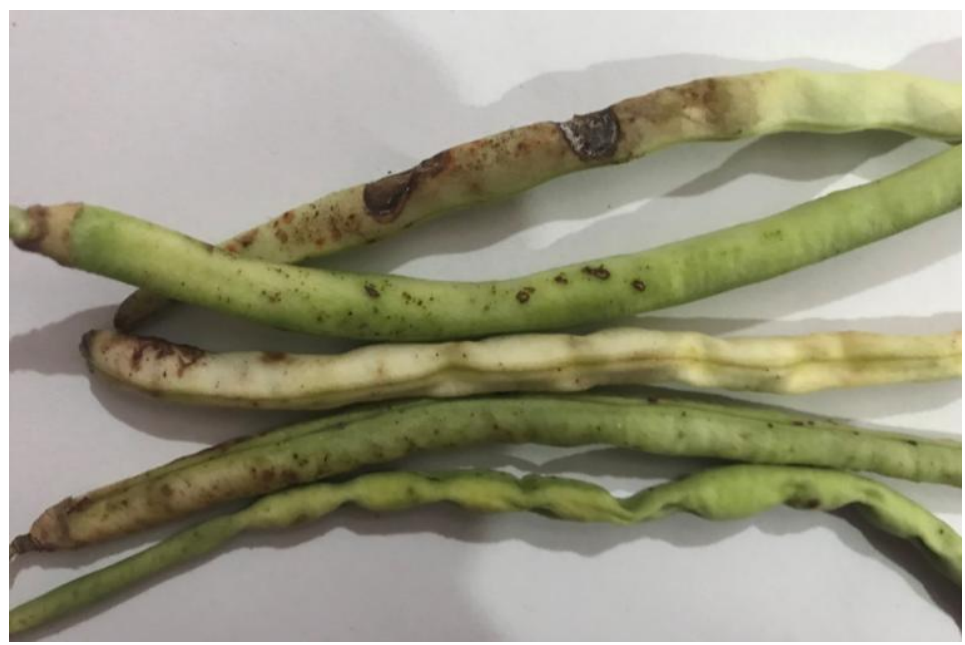

Fig.1 Symptoms on pods

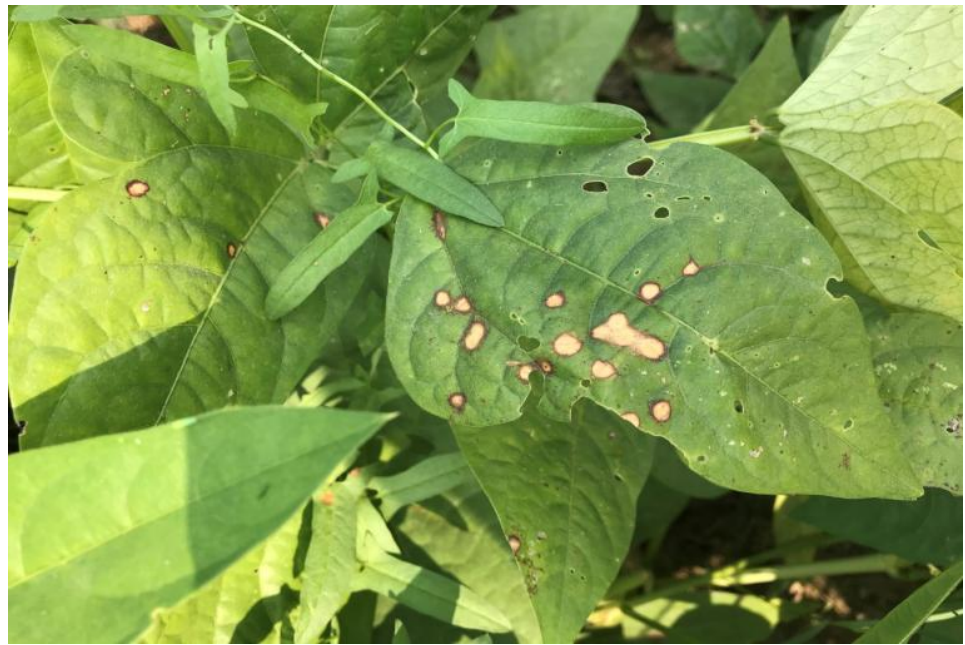

Fig.2 Symptoms on leaves

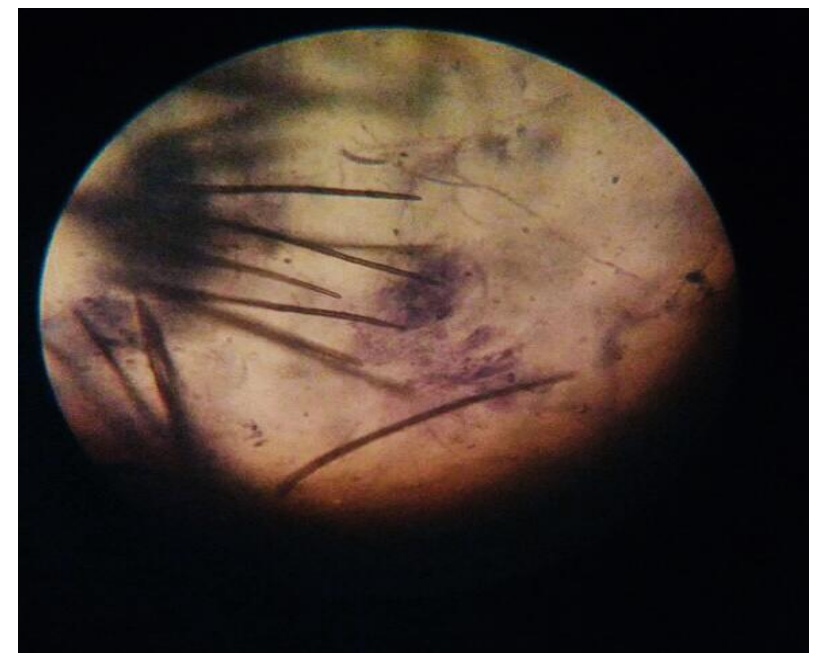

Fig.3 Photomicrograph of Colletotrichum lindemuthianum 


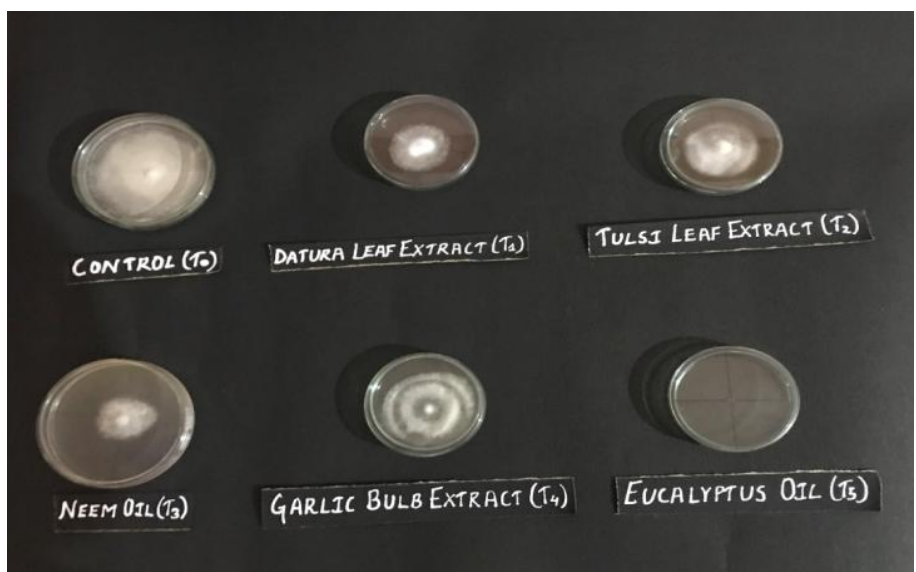

Fig.4 Poisoned Food technique of Botanical against Colletotrichum lindemuthi

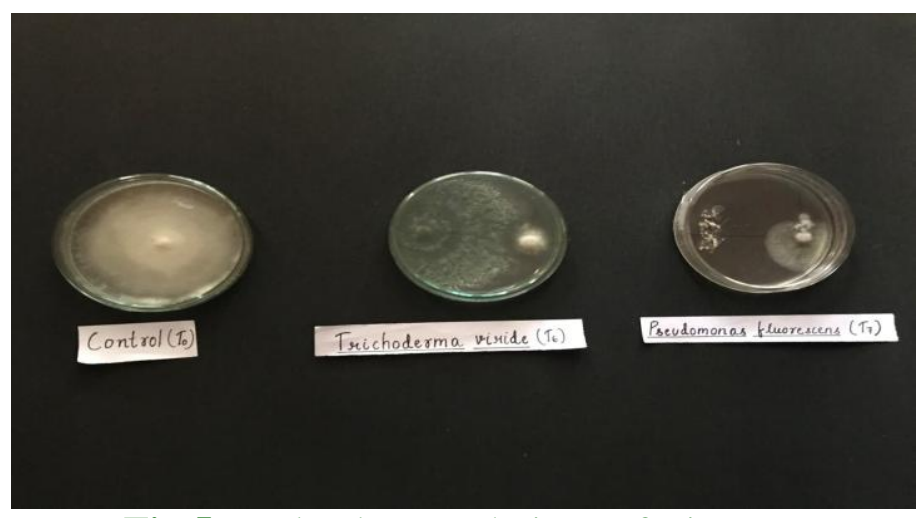

Fig.5 Dual culture technique of Biagents

It is seen from my trials that foliar spray of Trichoderma viride @ $2 \%$ were most effective in decreasing the disease intensity of Anthracnose of cowpea followed by Pseudomonas fluorescens @2\%.

Hence, this results were similar to the results of ofHegde et al., (2002). Under lab condition Eucalyptus oil @ 5\% gave the best result in inhibiting mycelial growth and hence this results were same as the results of Ramezani et al., (2002).

From the present studies it can be concluded that Eco-friendly management of Anthracnose disease of cowpea can be done by both botanicals as well as bio-agents as biological control is an important and integral part of integrated plant disease management system, especially against seed borne plant pathogens.

Bio-agents were more effective than the plant extracts. Trichoderma viride @ 2\% plays a important role in the growth of plant height as well as management of this disease both in the insitu as well as exsitu. But Pseudomonas fluorescens @ 2\% fails in the invitro condition with least inhibition per cent.

The Eucalyptus oil @ 5\% plays a major role in invitro condition with 100 per cent inhibition per cent as compared to other. All other plant extracts @ 5\% also played a major role in management of Anthracnose disease of cowpea. 


\section{References}

Hegde, G. M., Anahosur, K. H. and Srikant Kulkarni,(2002a), Biological control of Colletotrichum capsici causing fruit rot of chilli. Pl. Path. Newslet., 20: 4-5.

National Research Council (2006). "Cowpea". Lost Crops of Africa: Volume II: Vegetables. Washington DC: The National Academies Press. pp. 104 117. doi:10.17226/11763. ISBN 0-30910333-9.

Ramezani H, Singh HP, Batish DRO, Kohli
RK (2002). Antifungal 9. activity of volatile oil of Eucalyptus citriodora. Fitoterapia. 2002;73:261-62.

Small, E. (2009).Top 100 food plants.NRC Research Press.p.104. ISBN 978-0-66019858-3.

Timko, M. P.; Ehlers, J. D.; Roberts, P. A. (2007). "Cowpea". In Kole, C.Pulses, Sugar and Tuber Crops,Genome Mapping and Molecular Breeding in Plants(PDF). 3. Berlin, Heidelberg: Springer-Verlag. pp. 49-67.

\section{How to cite this article:}

Maria Modi and Shashi Tiwari. 2020. Eco-friendly Management of Anthracnose Disease of Cowpea (Vigna unguiculata) Sacc. \& Magn. Int.J.Curr.Microbiol.App.Sci. 9(02): 2720-2725. doi: https://doi.org/10.20546/ijcmas.2020.902.309 